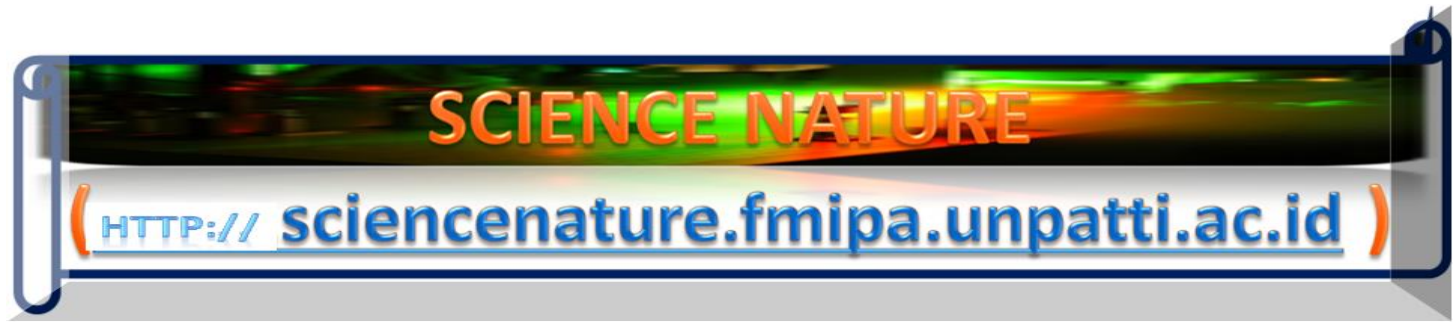

Science Nature 2(1), pp.042-056 (2019)

e-ISSN: 2654-6264

DOI: https://doi.org/10.30598/SNVol2Iss1pp042-056year2019

\title{
INFLUENCE OF ORGANIC FERTILIZER SAGO COMPOST ON \\ ULTISOLS SOIL PHYSICAL PROPERTIES OF TELAGA KODOK \\ SUB VILLAGE IN HITU VILLAGE OF CENTRAL MALUKU \\ DISTRICT AND THE CORN (Zea Mays Ceratina) CORPS \\ PRODUCTION
}

Silwanus M. Talakua*, Elizabeth Kaya

Soil Science Department, Faculty of Agriculture, Pattimura University (UNPATTI),

Jl. Ir. Martinus Putuhena, Kampus Poka, Ambon, Indonesia 97233

Received : July 24, 2018

Revised : November 30, 201

Published : December 24, 2018

Copyright @ All rights are reserved by Silwanus M. Talakua and Elizabeth Kaya

Corresponding author: *Email: silwanustalakua@yahoo.com 
Influence of Organic Fertilizer Sago Compost on Ultisols Soil Physical Properties of Telaga Kodok Sub in Hitu Village of Central Maluku District and the Corn (ZeaMays Ceratina) Corps Production

\section{Abstract}

This study aims to prove that the giving of organic fertilizer sago compost can improve soil physical properties and improve yields of maize crops on Ultisols. This research was conducted in Telaga Kodok Subvillage, Hitu Village Central of Maluku District in April 2016 until its completion. Soil analysis was conducted at Balai Penelitian Tanah Bogor. This research used Factorial Random Block Design which consist of one factor and repeated three times with compost dosage of sago compost is $\mathrm{K} 0$ (no compost), K1 (30 ton/ha), K2 (45 ton/ha), K3 (60 ton/ha ). Giving the ela sago compost can improve soil physical properties that is able to reduce the bulk density $\left(0.73 \mathrm{~g} / \mathrm{cm}^{3}\right)$, particle density $\left(1.78 \mathrm{~g} / \mathrm{cm}^{3}\right)$ and rapid drainage pores $(7.69 \%)$ and able to improve/increase moisture content of field capacity $(43.91 \%)$ and water available pore $(17.00 \%)$. The ela sago compost as organic fertilizer can increase the yield of corn crop is 89,80 $\mathrm{g} /$ plant or 4,28 t/ha. The optimum dosage of ela sago compost as organic fertilizer found to improve soil physical properties and increase the yield of corn crop is $60 \mathrm{t} / \mathrm{ha}$.

Keywords: Organic Fertilizer Sago Compost, Soil physical properties, Ultisols, Corn production

\section{ARTICLES}

\section{Introduction}

Organic farming system is a cultivation system using natural materials without chemicals. This organic farming needs to be developed to improve the quality of the soil in a sustainable manner in improving agricultural productivity for the long term.

Corn production in Maluku Province is targeted to reach 14,930 tons by the end of 2015 [1-5], but in 2014 corn production in Maluku Province reaches only 10,560 tons and in 2015 increased to 13,947 tons [4]. This fact shows that although corn production is increasing every
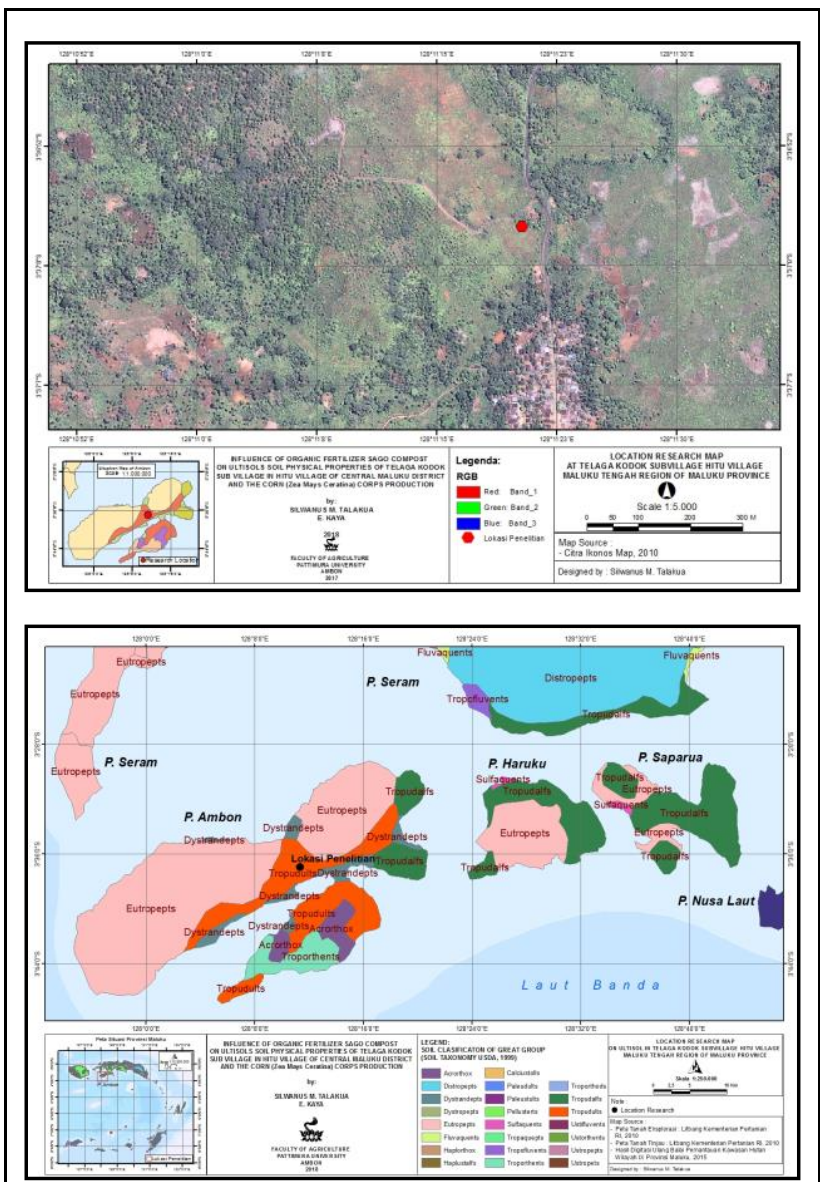

year but until now the production of maize in Maluku is still below national production targets so that efforts need to be made in order to increase production and self-sufficiency of corn.

Ultisol soil is one of the marginal land in the small island of Maluku which is acidic, so it is less support the growth of plants growing on this land because it has many obstacles, especially from soil physical and chemical properties. Some obstacles of the soil physics are fine texture of the soil and a high clay content causes poor soil porosity thus limiting root plant growth. Well drainages needed by plants that require good aeration such as corn. Well soil aeration causes the availability of oxygen in the 
Influence of Organic Fertilizer Sago Compost on Ultisols Soil Physical Properties of Telaga Kodok Sub in Hitu Village of Central Maluku District and the Corn (Zea Mays Ceratina) Corps Production

044

soil enough so that plant roots are able to absorb nutrients and good growing [6-22].

According to Ref. [21] it is said that one of the functions of the soil is for crop production. The physical properties of the soil strongly support the production of plants, although a soil type has good chemical properties but is not accompanied by good physical properties then the production of plants will not reach the maximum. Therefore, efforts to improve the physical properties of the soil is absolutely done in an effort to support the growth and production of plants [8].

Efforts to improve the quality of soil have been done, among others, by the giving of organic materials. The use of organic matter on marginal lands with major problems of poor soil physical properties such as high density and penetration resistance and low water retention generally yield better results than fertilizers intended to improve chemical properties only. This is because the giving of organic materials can not only contribute $\mathrm{N}, \mathrm{P}, \mathrm{K}$ and other elements, but also can improve the physical and biological properties of the soil [2].

The organic material used in this research is sago compost, because sago plant is one of the specific plants that grow predominantly on wetlands in the small islands of Maluku (archipelago region). According to Flach (1997) in [13], the area of sago palm in the Maluku Province reaches 60,000 ha, consisting of 50,000 ha grown naturally, and 10,000 ha is cultivated sago plant.

According to Ref. [19] sago palm is a subject of both concern and interest in the context of food security because of its high productivity and tolerance to high salt and acid in the soil. So according to Ref. [19] however, the compatibility of sago-based agriculture with natural forest has not been sufficiently assessed.

Ela sago which is also referred to as the pith slurry is the remainder of the process of sago starch extraction. Sago starch is the main result as the staple food of the people of Maluku. While the dregs (ela sagu) has some of the benefits of, for instance as a compost fertilizer maker [13]. Thus, the Province of Maluku has abundant raw materials as a source of compost (organic material) from sago plants that are useful in the sustainable development of small island farms in Maluku.

Organic matter plays a role in the process of granulation and aggregation so as to form stable soil aggregates and crumbly and lightweight soil structures based on Ref. [2]. Organic fertilizers activate many species of soil microorganisms that release phyto-hormones to stimulate plant growth and improve nutrients [16].

From the research results of Ref. [10] that the giving of sago compost (ela sagu) together with SP-36 fertilizer can improve the soil chemical properties of Ultisol, such as the increase of soil pH, P-available soil, $\mathrm{P}$ uptake, also can improve the physical properties of Ultisol soil reducing the bulk density and particle density, increases soil porosity, the soil pore size distribution includes slow drainage pore and rapid drainage down, increasing available water pore and improving soil aggregate stability.

Until now, research on soil physical properties in Land Management Study Program of Pattimura University is still lacking, while generally only conducted studies on soil chemical and soil biology, so based on the description above, it is necessary to do research on the influence of giving organic fertilizer sago compost and liquid organic fertilizer to soil physical properties and corn yields on Ultisols, each of which was observed and analyzed at different doses of fertilizers.

The aims of this research are 1) to prove that the giving of sago compost as organic fertilizer can improve the soil physical properties and improve the yield of corn crops; 2) find the optimum dose that can be suggested to improve soil physical properties and improve yield of corn crops. Hypotheses are: giving of organic fertilizer ela sago compost, will improve soil physical properties and increase (improve) yield of corn crop. 
Influence of Organic Fertilizer Sago Compost on Ultisols Soil Physical Properties of Telaga Kodok Sub in Hitu Village of Central Maluku District and the Corn (Zea Mays Ceratina) Corps Production

\section{EXPERIMENTAL METHOD}

\subsection{Place And Time of Research}

This research was conducted in Telaga Kodok Sub Village Hitu Village Maluku Tengah District atMaluku Province - Indonesian Country, and started on April 2016 until it was completed.

\subsection{Materials and Tools}

The materials used in this research are Ultisols soil in Telaga Kodok Sub Village, sago compost as organic fertilizer made from cow dung, PGPR/bioactivator, gamal leaf, rice husk, straw, eggshell, sugar. Besides that, it was also prepared bucket, pesticide solution vegetables, sample plastic bags, Kumala-F1 corn seeds as well as materials for soil profile profile ie soil profile description cards, soil $\mathrm{pH}$ papers, $\mathrm{H}_{2} \mathrm{O}_{2}$ solutions, Soil Munsell Color Charts, meters, name labels and chemicals for laboratory analysis.

The tools used are hoe, shovel, machete, rope, meter, bucket, soil ring sample, chopper machine, scales, measuring cylinders, and soil profile observation equipment ie blade field, abney level, computer and stationery.

\subsection{Research Methods}

The research treatment was factorial pattern arranged according to randomized block design (RBD) with 3 (three) replications. The factor is the organic fertilizer sago compost factor $(\mathrm{K})$ compound which consists of four dosage levels, namely: $(\mathrm{K} 0)=$ no compost; $(\mathrm{K} 1)=30 \mathrm{t} / \mathrm{ha} ;(\mathrm{K} 2)=45 \mathrm{t} / \mathrm{ha} ;(\mathrm{K} 3)=60 \mathrm{t} / \mathrm{ha}$, of the 4 units of combination treatment and three replications, 12 experimental units were obtained. The parameters measured were soil physical properties analysis, includes : bulk density of soil, soil density, rapid drainage pore, field capacity, water available pore, and crop production ie dry weight kernels in each corn plant.Data were analyzed by univariate variety analysis, with equation: $Y=\mu+\alpha i+\beta j+\varepsilon k$; where $Y=$ response variable; $\mu=$ mean value; $\alpha i=$ the influence of the $i$ th group; $\beta \mathrm{j}=$ the influence of the $\mathrm{j}$-th ela sago compost as organic fertilizer factor; $\varepsilon \mathrm{k}=$ experimental error $\mathrm{k}$, while differences are tested by LSD test (Least Significant Difference) [20]. In addition, to know the relationship between response variables due to treatment is done by linear regression analysis includes linear and nonlinear correlation with model: $\mathrm{Yi}=\beta \mathrm{o}+\beta 1 \mathrm{Xij}+\varepsilon \mathrm{i}[\mathbf{6 , 1 4}]$. All data were analyzed using SPSS17 and Minitab16 programs.

The research stages consist of initial work, field work and laboratory analysis. The initial work includes: composting sago compost with a ratio of liquid and solid is 2: 1. Field work includes: observation of soil profile in the field, clearing of land, making beds, planting corn seeds, plant maintenance, intact sampling with ring sample for the measurement of soil physical properties, observation of plant production parameters through measurement of dry weights of corn crops. Further analysis of soil physical properties conducted in Soil Research Laboratory in Bogor, including measurement of bulk density, particle density, rapid drainage pore, field capacity and available water pore, while measurement of dry weight of corn kernels is done in Soil, Water and Plant Analysis Laboratory of Faculty of Agriculture Pattimura University in Ambon.

\section{RESULTS AND DISCUSSION}

\subsection{The Effect of Giving Organic Fertilizer Ela} Sago Compost on Bulk Density of the Soil

The results of the RBD variety test showed that the composting of sago had significant effect on the decrease of the bulk density of the Ultisols.

After further tests of LSD of ela sago compost, as shown in Table 3.1, it is seen that dose increase from 0 $\mathrm{t} / \mathrm{ha}$ to $30 \mathrm{t} / \mathrm{ha}$ has no significant effect on bulk density of Ultisols soil, but if the dose is increased to $45 \mathrm{t} / \mathrm{ha}$ will have a significant effect in reducing the bulk density of the soil up to $0.73 \mathrm{~g} / \mathrm{cm}^{3}$ and then not significantly different in the treatment of $60 \mathrm{t} / \mathrm{ha}$. 
Influence of Organic Fertilizer Sago Compost on Ultisols Soil Physical Properties of Telaga Kodok Sub in Hitu Village of Central Maluku District and the Corn (Zea Mays Ceratina) Corps Production

From the table it is also seen that the average of bulk density for all compost treatment is smaller than the field bulk density $0.89 \mathrm{~g} / \mathrm{cm}^{3}$ with $\mathrm{K} 0\left(0.84 \mathrm{~g} / \mathrm{cm}^{3}\right), \mathrm{K} 1$ $\left(0.85 \mathrm{~g} / \mathrm{cm}^{3}\right), \mathrm{K} 2\left(0.73 \mathrm{~g} / \mathrm{cm}^{3}\right)$ and $\mathrm{K} 3\left(0.77 \mathrm{~g} / \mathrm{cm}^{3}\right)$ so it can be said that the compost dose of $45 \mathrm{t} / \mathrm{ha}$ has produced the lowest bulk density of $0.73 \mathrm{~g} / \mathrm{cm}^{3}$ and is the optimum compared with other treatments in reducing the level of soil density.

Table 3.1. LSD Test Result Effect of Single Factor Organic Fertilizer Sago Compost Treatment on Bulk Density of the Soil.

\begin{tabular}{cc}
\hline $\begin{array}{c}\text { Ela Sago Compost } \\
\text { Treatment (t/ha) }\end{array}$ & $\begin{array}{c}\text { Average of Bulk Density of } \\
\text { the Soil }\left(\mathbf{g} / \mathbf{c m}^{3}\right)\end{array}$ \\
\hline K0 (0 t/ha) & $0.84 \mathrm{a}$ \\
K1 (30 t/ha) & $0.85 \mathrm{a}$ \\
K2 (45 t/ha) & $0.73 \mathrm{~b}$ \\
K3 (60 t/ha) & $0.77 \mathrm{~b}$ \\
\hline
\end{tabular}

Note: The numbers followed by the same letter, are not significantly different at the 5\% significance level accordingly further test of LSD with $\mathrm{LSD}_{0.05}$ value single factor $\mathrm{K}=0.03$.

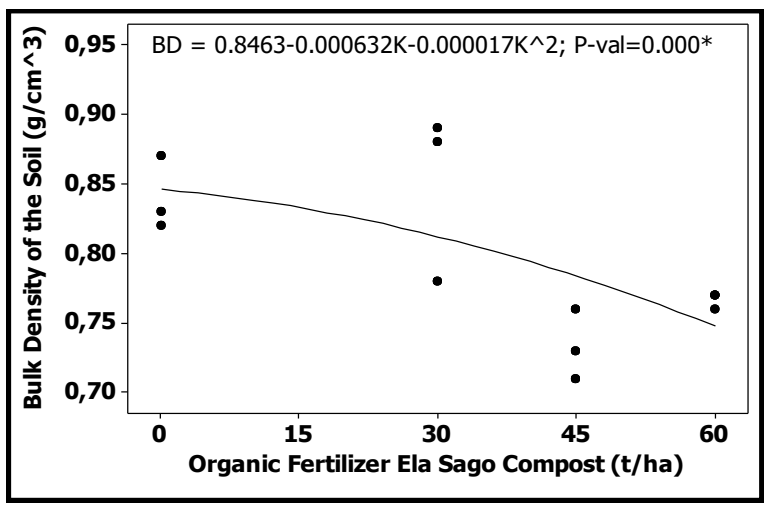

Figure 3.1.Regression Analysis/Equation of Organic Fertilizer Ela Sago Compost to Bulk Density of the Soil on Ultisols in Telaga Kodok Sub Village.

From the results of laboratory analysis, it is known that sago compost compost contains nutrients of $\mathrm{Ca}$ and $\mathrm{Mg}$ which are useful to improve soil structure to produce more granular soil, which is indicated by decrease of soil density (bulk density of soil). Besides, the compost of sago contains nutrients $\mathrm{N}, \mathrm{P}, \mathrm{K}, \mathrm{Ca}, \mathrm{Mg}, \mathrm{S}$ which play a role in decreasing soil acidity and support growth and development of corn crop at Ultisols in Telaga Kodok Sub Village.

From the results of this study it is known that the ela sago compost give a significant effect on changes in the bulk density of the soil content where the higher the ela sago compost dose given the bulk density of the soil value will tend to be lower (Figure 3.1). This is indicated by the $\beta 1$ regression coefficient $=-0,000632$ and $\beta 2=$ $-0,00017$ with P-Value $=0,000 *$ (significant).

Compost containing colloidal organic material with particle size $<1 \mu \mathrm{m}$ is an adhesive agent between particles in soil aggregate forming process. Colloidal organic matter in ela sago compost is the result of activity and reshuffling microbial cells containing mucus (gum) as a binding agent in the aggregation process. Organic polymers that are large molecular weight polysaccharides are derived from the walls of microbial cells forming tissue such as a net that is effective in uniting soil particles. These hydroxyl polymers and the clay-carbon oxygen atoms form hydrogen bonds as binding bridges, while the non-colloidal particles of these polymers act as adhesive glue.

The treatment of ela sago compost on Ultisols soil gives a significant effect on the change of bulk density of the soil where the higher the dose of fertilizer given the lower the bulk density of the soil. From the result of the research, it is known that ela sago compost treatment with dose 45 t/ha can significantly influence to the change of bulk density of the soil contents in which the existence of organic material on ela sago compost play in binding soil particles to form soil aggregate.

This is in line with the opinion of [23-25] that the fiber residues consist of lignin, cellulose and hemicellulose, which can easily generate chemical bonding with electrophiles via hydroxyl groups. This carboxyl group which functions for the formation of soil 
Influence of Organic Fertilizer Sago Compost on Ultisols Soil Physical Properties of Telaga Kodok Sub in Hitu Village of Central Maluku District and the Corn (Zea Mays Ceratina) Corps Production

structures. So are the opinion in Ref. [3] that, complex organic compounds resulting from the decomposition process of organic matter can serve as adhesive cement in the granulation process. This is also supported by research results from Ref. [23] who argue that research has shown that bio-char as organic fertilizer application can reduce soil bulk density, improve soil water-holding capacity. In accordance with the opinion based on Ref. [24] that organic fertilizer (corn-composite) can reduced the bulk density of tobacco- growing soil.

\subsection{The Effect of Giving Organic Fertilizer Ela Sago Compost on Particle Density of the Soil}

The results of the RBD variety test showed that the ela sago compost had significant effect on the particle density of the Ultisols.

After further test of LSD test of ela compost, as shown in Table 3.2, it can be seen that the increase of ela sago compost dose from 0 t/ha to $30 \mathrm{t} / \mathrm{ha}$ and $45 \mathrm{t} / \mathrm{ha}$ has no significant effect on the particle density of the soil, and then if dose is increased to $60 \mathrm{t} / \mathrm{ha}$ it will have a significant effect on the particle density of the soil. It is indicated by the regression coefficient $\beta 1=-0.001401$ and $\beta 2=-0000092$ with $\mathrm{P}-$ Value $=0.004^{*}$ ( significant), as shown in Figure 3.2. This is in line with the opinion of Sarief (1989) that the presence of organic matter on the soil causes the value of the particle density of the soil to be lower.

From Figure 3.2 above shows that the addition of ela sago compost on Ultisols soil will decrease the particle density of the soil where the higher ela sago compost content is given then the particle density of the soil be lower, then it is said that the ela sago compost will give more influence optimum to the particle density of the soil at treatment at a dose of $60 \mathrm{t} / \mathrm{ha}$.

The results also proved that the addition of ela sago compost can reduce the particle density of the soil with detail are : without treatment with a dose of $0 \mathrm{t} / \mathrm{ha}$ is $2.16 \mathrm{~g} / \mathrm{cm}^{3}$ to $2.09 \mathrm{~g} / \mathrm{cm}^{3}$ (30 t/ha), $1.85 \mathrm{~g} / \mathrm{cm}^{3}$ (45 $\mathrm{t} / \mathrm{ha}$ ) and $1.78 \mathrm{~g} / \mathrm{cm}^{3}$ (60 t/ha).It was assumed that the particle density of Ultisols soil before treatment was equal to the general particle density between $2.6-2.7$ $\mathrm{g} / \mathrm{cm}^{3}$ with an average of $2.65 \mathrm{~g} / \mathrm{cm}^{3}$. After being given the addition of ela sago compost into the soil it can reduce the particle density of the soil. It can be explained that the ela sago compost has the potential to decrease the particle density because weight of ela sago compost is lighter than the particle density of clay particle.

Table 3.2. LSD Test Result Effect of Single Factor Organic Fertilizer Ela Sago Compost Treatment on Particle Density of the Soil.

\begin{tabular}{cc}
\hline $\begin{array}{c}\text { Ela Sago Compost } \\
\text { Treatment (t/ha) }\end{array}$ & $\begin{array}{c}\text { Average of Particle } \\
\text { Density of the Soil }\left(\mathbf{g} / \mathbf{c m}^{\mathbf{3}}\right)\end{array}$ \\
\hline K0 (0 t/ha) & $2.16 \mathrm{a}$ \\
K1 (30 t/ha) & $2.09 \mathrm{ab}$ \\
K2 (45 t/ha) & $1.85 \mathrm{~b}$ \\
K3 (60 t/ha) & $1.78 \mathrm{c}$ \\
\hline
\end{tabular}

Note: The numbers followed by the same letter, are not significantly different at the $5 \%$ significance level accordingly further test of LSD with $\mathbf{L S D}_{\mathbf{0 . 0 5}}$ value single factor $\mathrm{K}=0.24$.

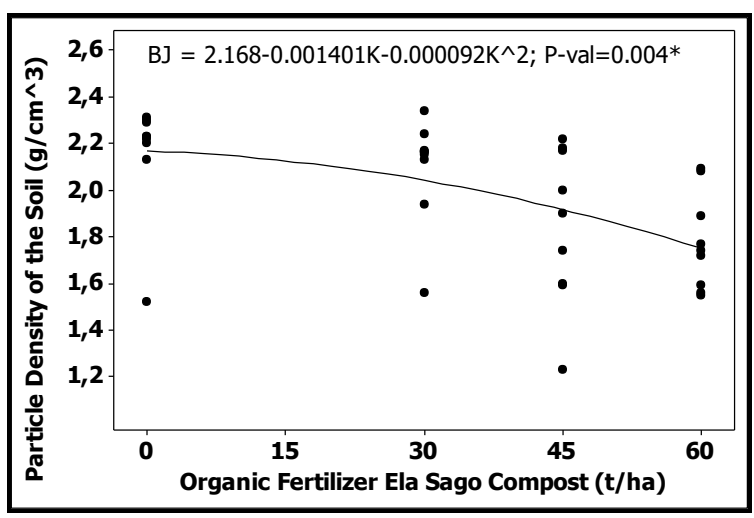

Figure 3.2. Regression Analysis/Equation of Organic Fertilizer Ela Sago Compost to Particle Density of the Soil on Ultisols in Telaga Kodok Sub Village. 
Influence of Organic Fertilizer Sago Compost on Ultisols Soil Physical Properties of Telaga Kodok Sub in Hitu Village of Central Maluku District and the Corn (Zea Mays Ceratina) Corps Production

Particle density of the each soil type tends to remain where the light weight of the particles is determined by the weathering levels of rocks which require considerable time, but the organic material contained in the ela sago compost can reduce the particle density of Ultisol soil in line with the addition of ela sago compost doses in each treatment performed. This is in line with the opinion of [18] that the presence of organic matter on the soil causes value of particle density of the soil will be lower.

The research results in Ref. [23-27] show that long-term application of organic fertilizer (manure) to change the composition of different size fractions due to cementation make $<2 \mu \mathrm{m}$ to reduce the content of soil particles, while the content of $2 \sim 10 \mu \mathrm{m}$ size fraction was significantly increased, which promote the formation of soil aggregate structure, improve soil physical and chemical properties of positive significance.

\subsection{The Effect of Giving Organic Fertilizer Ela Sago \\ Compost on Rapid Drainage Pore of the Soil}

The results of the RBD variety test showed that giving the ela sago compost was significantly affected to decrease by the rapid drainage pore of the Ultisols.

After the further test of LSD of ela sago compost, as shown in Table 3.3 it appears that the giving of ela sago compost with dose 0 t/a to 30 t/ha and 45 t/ha has no significant effect on rapid drainage pore, but if this dose increased to $60 \mathrm{t} / \mathrm{ha}$ it will have a significant effect in decrease of rapid drainage pore.

The addition of compost at a dose of 60 t/ha will decrease the percentage of the pore of rapid drainage up to 7.69 percent indicating that the more compost provided the water losses due to gravity will decrease so as to allow water to be retained on the soil pore as water is available to the plant.

Regression analysis results as depicted in Fig. 3.3 also showed that the higher the ela sago compost dosage that was given, the rapid drainage pores would tend to decrease. It is indicated by regression coefficient $\beta 2=-0.003713$ with P-Value $=0.015^{*}$ ( significant $)$.

Table 3.3. LSD Test Result Effect of Single Factor Organic Fertilizer Ela Sago Compost Treatment on Rapid Drainage Pore of the Soil.

\begin{tabular}{cc}
\hline $\begin{array}{c}\text { Ela Sago Compost } \\
\text { Treatment (t/ha) }\end{array}$ & $\begin{array}{c}\text { Average of Rapid } \\
\text { Drainage Pore of the } \\
\text { Soil }(\%)\end{array}$ \\
\hline K0 (0 t/ha) & $18.11 \mathrm{a}$ \\
K1 (30 t/ha) & $14.36 \mathrm{a}$ \\
K2 (45 t/ha) & $16.57 \mathrm{a}$ \\
K3 (60 t/ha) & $7.69 \mathrm{~b}$ \\
\hline
\end{tabular}

Note: The numbers followed by the same letter, are not significantly different at the $5 \%$ significance level accordingly further test of LSD with $\mathbf{L S D}_{\mathbf{0 . 0 5}}$ value single factor $\mathrm{K}=6.51$.

It needs to be explained that the existence of rapid drainage pore in large quantities, is not good for the stability of water binding in the soil matrix, because in this condition water will quickly disappear from the soil through gravity, infiltration and evaporation, thus becoming unavailable to the plant. Giving ela sago compost will help to improve soil structure by decreasing pore size > 29 micron as drainage pore, so soil water is not lost quickly, otherwise it will potentially become available for the plant.

Rapid drainage pores > 29.7 microns where this condition water is unavailable/ useless for plants because the water in this pore moves rapidly and disappears quickly through infiltration or evaporation and gravitational forces. The more rapid drainage pore then it is not good for the plant because the water is quickly lost. 
Influence of Organic Fertilizer Sago Compost on Ultisols Soil Physical Properties of Telaga Kodok Sub in Hitu Village of Central Maluku District and the Corn (Zea Mays Ceratina) Corps Production

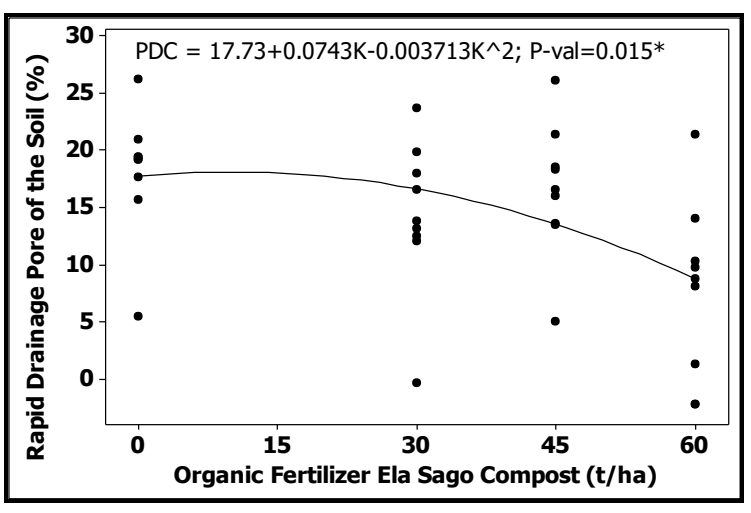

Figure 3.3. Regression Analysis/Equation of Organic Fertilizer Ela Sago Compost to Rapid Dainage Pore of the Soil on Ultisols in Telaga Kodok Sub Village.

This study proves that by giving ela sago compost the water lost by gravity at a pressure of $\mathrm{pF} 0.0-0.2$ will not be completely depleted or completely lost but there is still water retained by particles with a strength between 0 - 0.096 atmospheres so water can be available for plants. The more ela sago compost provides, the more water that can be tied to the surface of adsorption complex in the soil. This is supported by research results [17] that the provision of ela sago compost was lowering the rapid drainage pore in the soil.

\subsection{The Effect of Giving Organic Fertilizer Ela Sago Compost on Moisture Content of Field Capacity of the Soil}

The results of the RBD variety test showed that the giving ela sago compost had significant effect on the increase of moisture content of the field capacity of the Ultisols.

Research results prove that the ela sago compost treatment with dose of $60 \mathrm{t} / \mathrm{ha}$ increased the moisture content of the field capacity by $43.91 \%$ higher than the moisture content of the field capacity with other compost treatment doses ie without treatment of $38.13 \%$, dose 30 t/ha of $40,47 \%$ and dose 45 t/ha equal to $38,54 \%$

(Table 3.4). The increase of dose of ela sago compost to
$30 \mathrm{t} / \mathrm{ha}$ and $45 \mathrm{t} / \mathrm{ha}$ was also not significantly different with dose $0 \mathrm{t} / \mathrm{ha}$, but giving ela sago compost with dose $60 \mathrm{t} / \mathrm{ha}$ had significant effect compared to other treatment, so it can be said that ela sago compost treatment with dose $60 \mathrm{t} / \mathrm{ha}$ is more optimum than the other doses to increase the moisture content of field capacity in Ultisols soil.

Table 3.4. LSD Test Result Effect of Single Factor Organic Fertilizer Ela Sago Compost Treatment on Moisture Content of Field Capacity in Ultisols Soil.

\begin{tabular}{cc}
\hline $\begin{array}{c}\text { Ela Sago Compost } \\
\text { Treatment (t/ha) }\end{array}$ & $\begin{array}{c}\text { Average of Moisture } \\
\text { Content of Field Capacity } \\
\text { of the Soil (\%) }\end{array}$ \\
\hline K0 (0 t/ha) & $38.13 \mathrm{a}$ \\
K1 (30 t/ha) & $40.47 \mathrm{ab}$ \\
K2 (45 t/ha) & $38.54 \mathrm{a}$ \\
K3 (60 t/ha) & $43.91 \mathrm{~b}$ \\
\hline
\end{tabular}

Note: The numbers followed by the same letter, are not significantly different at the $5 \%$ significance level accordingly further test of LSD with $\mathrm{LSD}_{0.05}$ value single factor $\mathrm{K}=3.78$.

The result of regression analysis in Figure 3.4 also shows that giving ela sago compost can increase the water content of field capacity ie the more ela sago compost given, the moisture content of the field capacity will be higher. This is indicated by the regression coefficient $\beta 1=-0.04272$ and $\beta 2=0.002034$ with $\mathrm{P}-$ Value $=0.023 *$ (significant $)$.

It can be explained that the moisture condition in the field capacity is the amount of moisture content in the soil after the gravity of the water drops altogether. 
Influence of Organic Fertilizer Sago Compost on Ultisols Soil Physical Properties of Telaga Kodok Sub in Hitu Village of Central Maluku District and the Corn (Zea Mays Ceratina) Corps Production

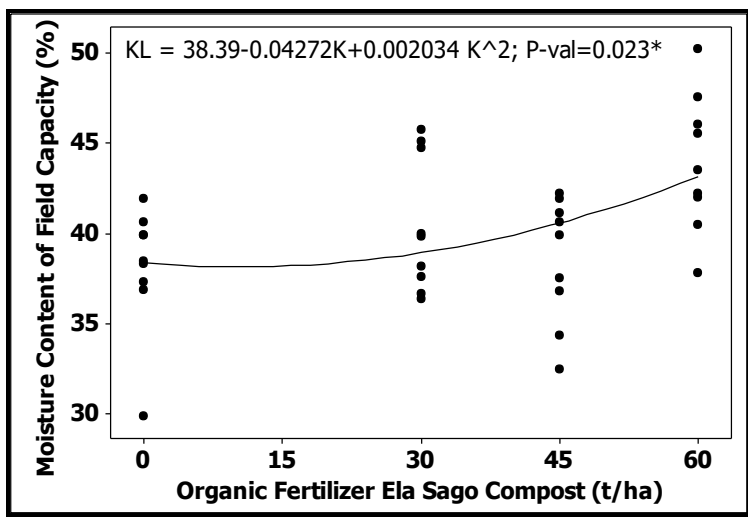

Figure 3.4. Regression Analysis/Equation of Organic Fertilizer Ela Sago Compost to Moisture Content of Field Capacity on Ultisols Soil in Telaga Kodok Sub Village.

The pore size of the field capacity is 8.7 microns and the water is held at a pressure of $\mathrm{pF} 2.54 \mathrm{pF}$ or $1 / 3$ atm. In this condition the soil contains the most water for plants, ie the macro pore is filled by air and water available, while the micro pores are filled entirely by water. The presence of organic materials, especially ela sago compost can improve soil structure, thus increasing the moisture content of the field capacity. This is in line with [18] opinion that the field capacity with high organic content is greater than the field capacity with low organic matter content. It is also supported by [1] that organic matter plays a role in the formation of soil structures and organic materials that begins to decompose has the ability to absorb and retain high water.According to Hendrichson in [9] soil water is available for plants from the field capacity to the permanent wilting point. Plant growth will not be disturbed if soil moisture levels are between the two conditions. In accordance with the opinion of [24] that organic fertilizer (corn-composite) can increased the porosity and water retention capacity of tobaccogrowing soil.

\subsection{The Effect of Giving Organic Fertilizer Ela Sago} Compost on Water Available Pore

The results of the RBD variety test showed that sago compost was significantly affected by the increase of water available pore of the Ultisols.

After further tests of LSD of ela sago compost, as shown in Table 3.5 it appears that the increase of ela sago compost to $30 \mathrm{t} / \mathrm{ha}$ and $45 \mathrm{t} / \mathrm{ha}$ has no significant effect on water available pore, but ela sago compost 60 t/ha treatment was significantly different from ela sago compost treatment with other doses in increasing water available pores on Ultisols soils.

Table 3.5. LSD Test Result Effect of Single Factor Organic Fertilizer Ela Sago Compost Treatment on Water Available Pore in Ultisols Soil.

\begin{tabular}{cc}
\hline $\begin{array}{c}\text { Ela Sago Compost } \\
\text { Treatment (t/ha) }\end{array}$ & $\begin{array}{c}\text { Average of Water Avilable } \\
\text { Pore of the Soil }(\%)\end{array}$ \\
\hline K0 (0 t/ha) & $11.88 \mathrm{a}$ \\
K1 (30 t/ha) & $13.37 \mathrm{a}$ \\
K2 (45 t/ha) & $11.76 \mathrm{a}$ \\
K3 (60 t/ha) & $17.00 \mathrm{~b}$ \\
\hline
\end{tabular}

Note: The numbers followed by the same letter, are not significantly different at the $5 \%$ significance level accordingly further test of LSD with $\mathbf{L S D}_{\mathbf{0 . 0 5}}$ value single factor $\mathrm{K}=3.25$.

The result of regression analysis as depicted in Figure 3.5 also shows that the higher the ela sagu compost dose given, the water available pore will increase. This is indicated by the regression coefficient $\beta 2=0.002468$ with P-Value $=0.011 *$ (significant $)$. 
Influence of Organic Fertilizer Sago Compost on Ultisols Soil Physical Properties of Telaga Kodok Sub in Hitu Village of Central Maluku District and the Corn (Zea Mays Ceratina) Corps Production

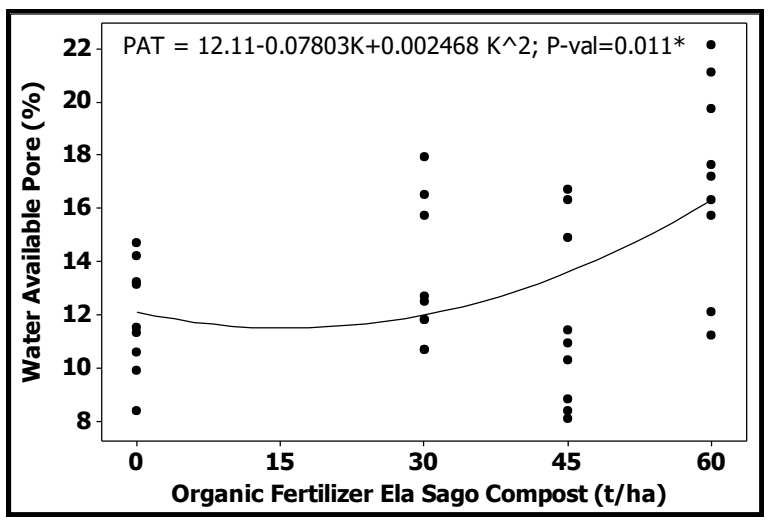

Figure 3.5. Regression Analysis/Equation of Organic Fertilizer Ela Sago Compost to Water Available Pore on Ultisols Soil in Telaga Kodok Sub Village.

Such data can be explained that the increased water available pore will increase the moisture content available on Ultisol soil in Telaga Kodok Sub Village. Research results show that the highest available water content is on the ela sago compost treatment with the dose of $60 \mathrm{t} / \mathrm{ha}$ is $17.00 \%$. The water available pore size is between $0.2-8.7$ microns ie at conditions between field capacity and permanent wilting point. In this condition the water can be directly absorbed by the root of the plant that is water with the strength of 0.333 to 15 atmospheres. Water under these conditions will be retained by the meso and micro pores and absorbed by the plant under optimum conditions. Giving the ela sago compost with higher doses results in increased moisture content available due to soil texture of Ultisols are fine with a large surface area and large pore volume that can bind water to the maximum. In accordance with the opinion of [7] which states that fine textured soils have a maximum total water binding capacity but the maximum available water is bonded to medium texture of the soils. In accordance with the opinion of [24] that organic fertilizer (corn-composite) can increased the porosity and water retention capasity of tobacco- growing soil.

Things is supported the research results $\mathrm{Xu}$ in [27] show that long-term application of organic fertilizer (manure) to change the composition of different size fractions due to cementation make $<2 \mu \mathrm{m}$ to reduce the content of soil particles, while the content of $2 \sim 10 \mu \mathrm{m}$ size fraction was significantly increased, which promote the formation of soil aggregate structure, improve soil physical and chemical properties of positive significance. The addition of ela sago compost means there is also an increase in the volume of water that is closely related to the availability of water in the soil.

\subsection{The Effect of Giving Organic Fertilizer Ela Sago Compost on Dry Weight of Pods Corn at Ultisols in Telaga Kodok Sub Village \\ The results of the RBD variety test showed that} the giving ela sago compost, organic liquid fertilizer and its interaction had a significant effect on the dry weight of corn pods at Ultisols in Telaga Kodok Sub Village.

After further tests of LSD on factor of ela sago compost as organic fertilizer, as shown in Table 3.6, it can be seen that the highest crop yield can be achieved in a treatment of K3 (ela sago compost $=60 \mathrm{t} / \mathrm{ha}$ ) of 89.80 grams compared with other treatment. It is seen that the higher the dosage of ela sago as organic fertilizer given the result of corn crop is increasing.

Table 3.6. LSD Test Result Effect of Single Factor Organic Fertilizer Ela Sago Compost Treatment on Dry Weight of Pods Corn (g/plant).

\begin{tabular}{cc}
\hline $\begin{array}{c}\text { Compost tratment } \\
\text { (ton/ha) }\end{array}$ & $\begin{array}{c}\text { Average of Dry Weight of } \\
\text { Pods Corn (g/plant) }\end{array}$ \\
\hline K0 (0 ton/ha) & $0.00 \mathrm{a}$ \\
K1 (30 ton/ha) & $62.31 \mathrm{~b}$ \\
K2 (45 ton/ha) & $79.26 \mathrm{c}$ \\
K3 (60 ton/ha) & $89.80 \mathrm{~d}$ \\
\hline
\end{tabular}

Note: The numbers followed by the same letter, are not significantly different at the 5\% significance level accordingly further test of $\mathrm{LSD}$ with $\mathrm{LSD}_{0.05}$ value single factor $\mathrm{K}=7.60$. 
Influence of Organic Fertilizer Sago Compost on Ultisols Soil Physical Properties of Telaga Kodok Sub in Hitu Village of Central Maluku District and the Corn (Zea Mays Ceratina) Corps Production

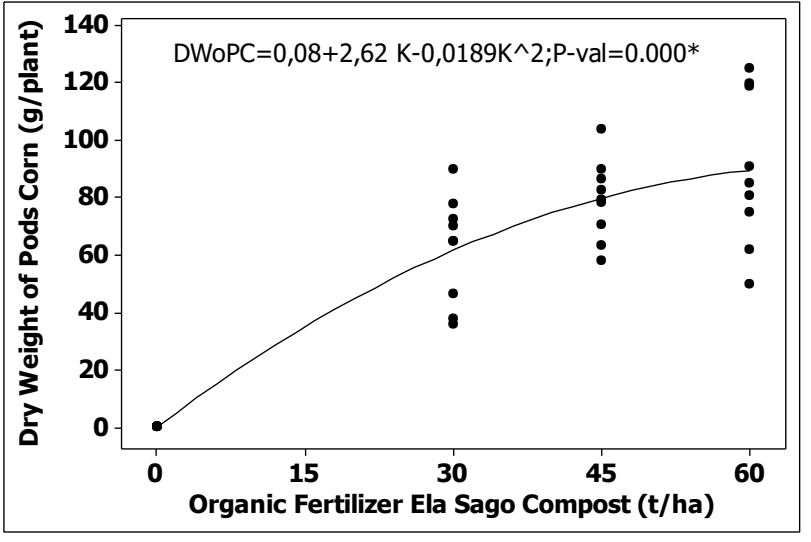

Figure 3.6. Regression Analysis/Equation of Organic Fertilizer Ela Sago Compost to Dry Wight of Pods Corn on Ultisols Soil in Telaga Kodok Sub Village.

It can be explained that the giving of ela sago compost causes the soil to have sufficient nutrient supply for plant growth especially $\mathrm{N}, \mathrm{P}, \mathrm{K}, \mathrm{Ca}, \mathrm{Mg}$ and other micro elements. In addition, this treatment contains microorganisms that break down the soil $\mathrm{N}$ and donate $\mathrm{N}$ to the plant. This means that the soil and plants get a large supply of $\mathrm{N}$ nutrients where the roots of the plant will move freely to absorb nutrients from the soil. All these nutrients are essential element that can be available in the soil and are useful to plants in support of better growth and crop production. Giving the ela sago compost has also improved the soil physical properties that is decrease of the bulk density, particle density, and rapid drainage pores, increasing the moisture content of the field capacity and water available pore (available moisture content), so that rooting is better to absorb nutrients from the soil. This is in line with the opinion of [26] that the fiber residues consist of lignin, cellulose and hemicellulose, which can easily generate chemical bonding with electrophiles via hydroxyl groups. This carboxyl group which functions for the formation of soil structures.

This is because the giving of organic materials can not only contribute N, P, K and other elements, but also can improve the physical and biological properties of the soil Ref. [2]. Also supported by [15] that the value of positive significant correlation coefficient between available moisture content and soil organic matter content, the higher the organic matter the higher the available moisture content in the soil. In addition, according to [16] that organic fertilizers activate many species of soil microorganisms that release fitohormon to stimulate plant growth and improve nutrition. The soil organism also requires nitrogen for its growth and development. It is also endorsed by [11] that giving ela sago compost will improve soil chemistry primarily lowering soil acidity, increasing $\mathrm{P}$-available and soil $\mathrm{P}$ uptake. Similarly, according to the study of [12] that the giving of $\boldsymbol{e l a}$ sago compost independently can increase the dry weight of corn plant in Ultisols. This is also supported by the results of research from [25] that application of organic fertilizer was all alkaline fertilizer, which provide phosphorus and potasium ions, and calcium and magnesium bases as well, contributing to improving acidified soil and apple fruit yield.

Study results of [27] showed that the application of organic fertilizer effectively, will increase soil $\mathrm{N}$ and maintain available $\mathrm{N}$, and increase available soil $\mathrm{K}$. as shown in Ref. [27] stated that long-term application of organic fertilizer can increase soil Fe-P, the content of Al-P, Ca2-P and organic phosphorus each component.

Recognizing the function and important role of organic fertilizer in increasing corn production, it can be recommended to use ela sago compost with dose $60 \mathrm{t} / \mathrm{ha}$ so that corn production can reach $4.28 \mathrm{t} / \mathrm{ha}$. It strongly supports the national corn production improvement program targeted to increase $5 \%$ per year with the average national corn production currently at $5.05 \mathrm{t} / \mathrm{ha}$ and especially in Maluku Province of $3.81 \mathrm{t} / \mathrm{ha}$.

\section{CONCLUSION}

\subsection{Conclusion}

Based on the results and discussion of this study it can be concluded several things as follows: 
Influence of Organic Fertilizer Sago Compost on Ultisols Soil Physical Properties of Telaga Kodok Sub in Hitu Village of Central Maluku District and the Corn (Zea Mays Ceratina) Corps Production

1. Ela Sago Compost can improve the bulk density, particle density, rapid drainage pore, field capacity and water available pore (moisture content available) at Ultisols soil in Telaga Kodok Sub Village.

2. The ela sago compost as organic fertilizer was able to increase the yield of corn plants that is $4.28 \mathrm{t} / \mathrm{ha}$.

4. The optimum dosage of ela sago compost found to improve soil physical properties of Ultisols is a dose of $60 \mathrm{t} / \mathrm{ha}$. Furthermore, to increase the production of maize, the best treatment as the optimum dose is 60 t/ha ela sago compost as organic fertilizer.

\subsection{Suggestion}

Based on the results of this study it is necessary to suggest several things as follows:

1. To improve the physical properties of Ultisols soil it is recommended only use organic fertilizer ela sago compost with optimum doses of $60 \mathrm{t} / \mathrm{ha}$.

2. To increase the production of maize in the Ultisols soil is advised to provide organic fertilizer ela sago compost with dosage of $60 \mathrm{t} / \mathrm{ha}$.

3. Need to do continue research on how to apply liquid organic fertilizer, either directly to the soil or through plant leaves to know the effect on soil physical properties and crop production at Ultisols in other location.

\section{Acknowledgement}

We are grateful to thank for Ministry of Research, Technology and Higher Education of Republic of Indonesia for providing funding for the implementation of this research.

\section{References}

[1] Arsyad S. 2006. Konservasi Tanah dan Air. IPB Press. Bogor. ISBN : 979-493-003-2

[2] Baskoro., D. P. T., 2010. Pengaruh Pemberian Bahan Humatdan Kompos Sisa Tanaman Terhadap Sifat Fisik Tanah dan Produksi Ubi Kayu. Jurnal Tanah dan Lingkungan Volume 12 No 1, Hal 9 - 14 April 2010. ISSN 1410-7333.
[3] Baver, L. D., W. H. Gardner \& W. R. Gardner, 1972.Soil Physics. $4^{\text {th }}$. Rd. John Wiley. New York.

[4] Dinas Pertanian Provinsi Maluku, 2016. Data Produksi Jagung di Provinsi Maluku.

[5] Dirjen Tanaman Pangan Kementerian Pertanian, 2015. Pedoman Teknis GPPTT Jagung 2015. (tidak dipublikasikan).

[6] Draper. N.R. dan H. Smith. 1992. Terjemahan Analisis RegresiTerapan. P.T.Gramedia PustakaUtama. Jakarta.

[7] Foth. H.D. 1990. Fundamentals of Soil Science. Eighth Edition. New. Michigan State University. John Wiley and Sons. ISBN: 0-471-52279-1.

[8] Haridjaja, O., Y. Hidayat., L.S. Maryamah., 2010. Pengaruh Bobot Isi Tanah Terhadap Sifat Fisik Tanah dan Perkecambahan Benih Kacang Tanah dan Kedelai. Jurnal Ilmu Pertanian Indonesia.Volume 15 No. 3.Desember 2010.Hal.147-152. ISSN 0853-4217.

[9] Hillel, D. 1971.Soil and Water. Physical Principles and Processes, New York: Academic Press, Inc.

[10] Kaya, E, J.A. Putinella dan F. Puturuhu, 2008. Pemanfaatan Limba Olahan Sagu (Ela Sagu) Sebagai pupuk Organik. Laporan Penelitian Maritim Fakultas Pertanian Universitas Pattimura Ambon.

[11] Kaya. E. 2012. Pengaruh Pemberian Kompos Ela Sagu dan Pupuk ABG Bunga-Buah Terhadap P Tersedia, Serapan P, serta Pertumbuhan Tanaman Jagung (Zea mays L.) Pada Inceptisols. Jurusan Budidaya Pertanian Fakultas Pertanian Universitas Pattimura Ambon. Jurnal Buana Sains Vol.12 No.1:21-26.

[12] Kaya E. Adelina Siregar. Diane M.Y. Matulessy, Masitta Hasan. 2016. Pertumbuhan Dan Produksi Tanaman Jagung (Zea Mays L.) Akibat Pemberian Kompos Ela Sagu Dan Pupuk Organik Cair (Poc) Pada Tanah Ultisol. Jurnal Budidaya Pertanian. Vol. 12(1): 16-19th. 2016 ISSN: 1858-4322.

[13] Louhenapessy J.E, M. Luhukay, S. Talakua, H. Salampessy, J. Riry. 2010. Sagu Harapan dan 
Influence of Organic Fertilizer Sago Compost on Ultisols Soil Physical Properties of Telaga Kodok Sub in Hitu Village of Central Maluku District and the Corn (Zea Mays Ceratina) Corps Production

Tantangan. PT. Bumi Aksara. Jakarta. ISBN: 978-979-010-518-8.

[14] Morrison D.F. 1976 Multivariate Statistical Methods.Second Edition.Mc.Graw-Hill Book Company. New York St. Louis San Francisco Auckland Düsseldorf Johannesburg Kulala Lumpur London Mexico Montreal New Delhi Panama paris São Paulo Singapore Sydney Tokyo Toronto.

[15] Murtilaksono K dan E. D. Wahyuni, 2004. Hubungan Ketersediaan Air Tanah dan Sifat-sifat Dasar Fisika Tanah. FakultasPertanian IPB, Bogor. Jurnal Tanah dan Lingkungan, Volume 6 No. 2, Oktober2004 : 46-50.

[16] Ouda, B. A and Mahadeen, A.Y. 2008. Effect of Fertilizers on Growth, yield, yield Components, Quality and Certain Nutrient Inbroccoli (Brassecaoleraceae). International Journal of Agriculture and Biology, 10 (6) 627-632.

[17] Putinella J.A. 2014. Perubahan Distribusi Pori Tanah Regosol Akibat Pemberian Kompos Ela Sagu Dan Pupuk Organik Cair. Jurusan Budidaya Pertanian Fakultas Pertanian Universitas Pattimura. Jurnal Buana Sains Vol. 14 No. 2:123-129.

[18] Sarief. S, H. E., 1989. Fisika-Kimia Tanah Pertanian. Penerbit CV. Pustaka Buana, Bandung.

[19] Sasaoka M, Y. Laumonier, K. Sugimura. 2014. Influence of Indigenous Sago-Based Agriculture on Local Forest Landscapes In Maluku, East Indonesia. Journal of Tropical Forest Science 26(1): 75-83. Graduate School of Letters, Hokkaido University, Kita 10, Nishi 7, Kita-ku, Sappora, 060-0810, Japan; mssasaoka@ let.hokudai.ac.jp.

[20] Steel R.G.D dan J.H. Torrie. 1991. Prinsip dan Prosedur Statistika. Suatu Pendekatan Biometrik. Terjemahan dari Principles and Procedure of Statistics. 1980. Copyright McGraw-Hill. Inc. Alihbahasa Ir. Bambang Sumantri (IPB). PT. Gramedia Jakarta.
[21] Talakua, S. M. 2016. DegradasiLahan; Metode Analisis dan Aplikasinya dalam Penggunaan Lahan. Plantaxia Press. Yogyakarta.

[22] Wirosoedarmo Ruslan, 2011. Evaluasi Kesesuaian Lahan untuk Tanaman Jagung Menggunakan Metode Analisis Spasial. Universitas Brawijaya. Jurnal Agritech, Volume 31 No. 1, Februari 2011.

[23] Xinliang Dong, Tianyu Guan, Guitong Li, Qimei Lin, Xiaorong Zhao. 2016. Long-Term Effects Of Biochar Amount On The Content And Composition Of Organic Matter in Soil Aggregates Under Field Conditions. Journal Soils Sediments (2016) 16:1481-1497 DOI 10.1007/s11368-015-1338-5. @Springer-Verlag Berlin Heidelberg.

[24] Yang LlU, Aihua Li. 2016. Effects of Corn Stalk - composted Organic Fertilizer on Physiochemical Properties of Tobacco-growing Soil. Agricultural Science \& Technology, 2016, 17(11): 2551-2554. Copyright @ 2016, Information Institute of HAAS.

[25] Yao SUN, Yiming WANG, Peiping ZHANG. 2016. Effect of Organic Fertilizer on Fruit Quality Acidified Soil Chemical Properties in Yantai Orchard. Agriculture Science and Technology. 17(5):1145-1148, 1165. @. Information Institute of HAAS.

[26] Zainab N, AR Khairul Aidil Azlin, S. Nazlima, H. Hasnain, Norhaizat, JX Teng, V. Lawai. 2013. Production of Fire-Retardant Sound-Absorbing Panels From Sago Waste. Journal of tropical forest Science 25(4): $510-515$. Department of chemistry, Faculty of Resource science and technology,Universiti Malaysia Sarawak, 94300 Kota Samarahan, Sarawak.

[27] ZhiQiang $\mathrm{Yu}$, FeiPeng Ren. 2015. Material Properties in Advances in Organic Fertilizer. Applied Mechanics and Materials Vol. 730 (2015) pp 235-240 (C) (2015) Trans Tech Publications, Switzerland. doi:10.4028/www.scientific.net/ $\underline{\text { AMM.730.235 }}$ 
Influence of Organic Fertilizer Sago Compost on Ultisols Soil Physical Properties of Telaga Kodok Sub in Hitu Village of Central Maluku District and the Corn (Zea Mays Ceratina) Corps Production

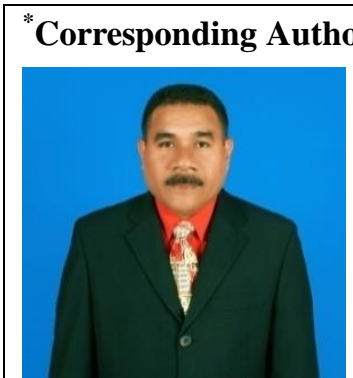

Dr. Ir. Silwanus Matheus Talakua, MP, born in Ambon, Maluku Province on January $3^{\text {rd }}$, 1965. Graduated with a Bachelor of Agriculture (S1) at Pattimura University in 1991 with Specialist in Soil Sciences/Soil and Water Conservation. In 1999 completing a Master Degree Program (S2) in the Program Postgraduate of Padjadjaran University in Bandung with the main spesification of study in Soil / Reclamation and Land Rehabilitation, then in 2009, won a Doctorate (S3) at Padjadjaran University with a science spesification in Soil Science, Land Degradation and Land Rehabilitation Sciences. Since 1993 to present the author is a Teaching Staff on the Soil Science and Agroecotechnology Study Program at Agriculture Faculty of Pattimura University. The courses taken are Soil Physics, Basic Soil Science, Hydrology, Soil and Water Conservation, Geodesy and Cartography, Degradation and Land Rehabilitation. Also as a teaching staff at the Postgraduate Program of Pattimura University in the Land Management Study Program, with the subjects being raised are Soil Physics, Land Resource Conservation, Land Rehabilitation, Land Use Planning, and Statistical Analysis. The research that has been done by Dr. Talakua is : the Study of Soil Degradation Through Estimation of Potential Erosion by the USLE method in the Wai Ruhu Watershed at Sirimau Sub District Ambon (1991), Determination of Erosion Hazard Levels in the Wai Lela Watershed at Ambon Bay Baguala Sub District Ambon City (1999 ), Analysis of Some Physical Properties of Soil, Land Use and Properties of Soil Profiles on Infiltration Processes in Wae Tonahitu Watershed at Ambon Bay Baguala Sub District, Ambon City (2002), Evaluation of Soil Degradation and Control Effort in the Wai Riuapa Watershed at Kairatu Sub District of Maluku Province ( 2006), Inventory of Sago Potential and Sago Mapping in Bula Sub District East Seram District (2009), Sago Development Survey in South Buru District (2009), Effects of Land Use on Soil Degradation Due to Erosion in Kairatu Sub District at West Seram District of Maluku Province (2009), Identification of watershed characteristics in Wai Batu Merah Watershed at Ambon City of Maluku Province (2012). The Effect of Land Use Extent and Vegetation Density on Soil Degradation in Mixed Plantation and Shifting Cultivation in Kairatu District, West Seram Regency, which was published in the Agrinimal Journal. Faculty of Agriculture Pattimura University, Vol. 3, No. 1 (2013). ISSN: 2088-3609. Evaluation of Land Capability and Landuse Planning in the Wai Tina Watershed, South Buru Regency, Maluku Province, which was published in the Agrologia Journal of the Agriculture Faculty Pattimura University Vol. 3, No. 1 (2014). ISSN: 2301-7287. Water Efficiency on Irrigation System in Way Bini of Waeapo Sub District, Buru District of Maluku Province, which was published in the Agrologia Journal of Agriculture Faculty, Pattimura University Vol. 5, No. 2 (2016). The Effects of Land Use Factors on Soil Degradation at Mixed Plantation in the Sub District of Kairatu, West Seram District, Maluku Province, published in the Agrologia Journal of the Agriculture Faculty Pattimura University Vol. 7, No. 1 (2018). Determination of Land Capability Class and Land Rehabilitation Planning at Wai Batu Merah Watershed in Ambon City, Maluku Province, which was published in the Agrologia Journal Vol. 7, No. 1 (2018). 
Dr. Talakua has been as a speaker at several scientific meetings: Annual Scientific Meeting (PIT) XXVIII Indonesian Hydraulic Engineering Expert Association (HATHI) (2011). "The Role of Integrated Watershed Management in Regional Development" at the Meeting for the Watershed Management of Integrated Wae Apu Watershed in Buru Regency (2011). Soil from the Side of Empowerment, Conservation. General Meeting of GPM Male Pastors in Maluku Province (2011). The Importance of Integration in Watershed Management at the Coordination Meeting on the Planning of the Integrated Management of the Wae Manumbai Watershed in Aru Islands Regency (2012). "Maluku in the Aspect of Disaster Presenters Papers on Activities for Dissemination of Disaster Risk Reduction in Ambon City for Elementary, Junior High School, Senior High School Teachers in Ambon City in collaboration with Ambon City Government cq Ambon City Regional Disaster Management Agency with Hope World Wide Indonesia (2013). As Oral Presenter in National Joint Conference Unpatti-Unpad. Sustainable Development For Archipelago Region in Pattimura University (2017). Determination of Innovative Patterns of Land Conservation at Wai Batu Merah, Wai Tomu, Wai Batu Gajah, and Wai Batu Gantung to Support Flood and Sediment Barriers at the National Seminar for the $51^{\text {st }}$ Anniversary of the Faculty of Agriculture, Mataram University in Lombok at Nusa Tenggara Barat Province (2018). Dr. Talakua as a participant in : International Seminar on Sago and Spices For Food Security. Sail Banda (Small Island for Our Future) Ambon (2010). Disaster Risk Reduction Training Program at Yogyakarta (2014). Training Data Analysis Experimental Design 2 Factors With Minitab 17 Program (2016). ArcGIS training for Basic Level in Center For The Development Of Spatial Data (PPIDS) of Pattimura University, Ambon City (2018). International Seminar Sago Feeds The World, in Ambon City (2018). The book that has been produced by Dr. Talakua is the book 1). "Sago, Hope and Challenges" First Edition on November 2010. Publisher: PT Bumi Aksara Jl. Sawo Raya No.18. Jakarta-13220 ISBN 978-979-010-518-8., 2). Land Degradation, Method of Analysis and Its Application on Land Use on 2016, Publisher : Plantaxia Publisher Yogyakarta. ISSN: 978-602-6912-13-8. Dr. Talakua, active in professional organizations, namely as Secretary of the Devision of Physics and Mechanics Science at the Indonesian Soil Science Association (HITI) KOMDA Maluku and Irian Jaya (1993-1996), member of the Indonesian Soil Science Association (HITI) (Deputy Chair of the HITI KOMDA Maluku), Secretary of the Watershed Forum of Maluku Province, member of the Water Resources Council of Maluku Province, member of Regional Spatial Planning Coordination Team (BKPRD) of Ambon City, member of Resources Management Coordination Team of Ambon-Seram River Region of Maluku Province.

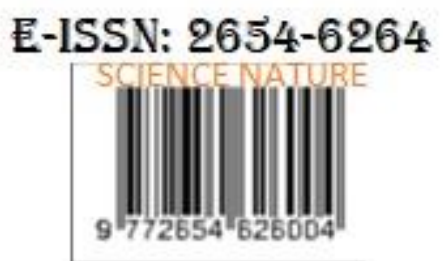

